Research Report No. 11/2009

\title{
Law's Knowledge and Law's Effectiveness: Reflections from Legal Sociology and Legal Theory
}

Peer Zumbansen

Osgoode Hall Law School of York University, PZumbansen@osgoode.yorku.ca

Follow this and additional works at: http:/ / digitalcommons.osgoode.yorku.ca/clpe

\section{Recommended Citation}

Zumbansen, Peer, "Law's Knowledge and Law's Effectiveness: Reflections from Legal Sociology and Legal Theory" (2009).

Comparative Research in Law \& Political Economy. Research Paper No. 11/2009.

http://digitalcommons.osgoode.yorku.ca/clpe/126 


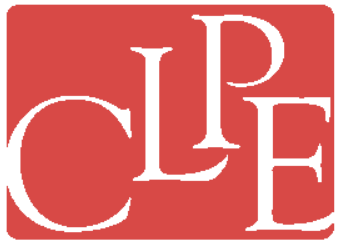

\section{Comparative Research in Law \& Political Economy}

\section{Peer Zumbansen}

\section{Law's Knowledge and Law's Effectiveness: Reflections from Legal Sociology and Legal Theory}

EDITORS: Peer Zumbansen (Osgoode Hall Law School, Toronto, Director, Comparative Research in Law and Political Economy, York University), John W. Cioffi (University of California at Riverside), Nassim Nasser (Osgoode Hall Law School, Toronto, Production Editor) 

CLPE Research Paper 11/2009

Vol. 05 No. 02 (2009)

\title{
Peer Zumbansen
}

\section{LAW'S KNOWLEDGE AND LAW'S EFFECTIVENESS: REFLECTIONS FROM LEGAL SOCIOLOGY AND LEGAL THEORY}

\begin{abstract}
Legal sociology is in a crisis - or so it is said. The field is not widely represented at Law Faculties today and, the claim goes, is in dire need of a new spirit. Meanwhile, scholars who are working in the area cover a wide array of research questions, ranging from criminology to family law, from urban governance to transitional justice, illustrating thus a fine sensitivity for important and fast evolving areas. This paper argues that indeed our times offer a great host of promising opportunities for legal sociological research. In midst of a truly dramatic economic crisis where anchoring points and orientations have been upset, a broad search for adequate regulatory responses is underway. In this climate of reassessing the lessons of reflexive and responsive law, of legal pluralism and 'law \& society' with view to their re-invigoration for our times, legal sociology is itself seemingly undergoing a transformation of its own: today's research methodology must pay heed to the advances made since Weber, Durkheim, Ehrlich and Gurvitch and translate them into a distinctly cross-disciplinary context, comparative and transnational context.
\end{abstract}

Keywords: Legal Sociology, Theory of the State, Solitude, Abandonment, Corporate Sponsorship, Knowledge, Legal Effectiveness

JEL classification: K30, K33

Peer Zumbansen

Canada Research Chair in the Transnational and Comparative Law of Corporate Governance

Osgoode Hall Law School, York University, Toronto.

Director, Critical Research Laboratory in Law \& Society www.criticalresearchlab.org

Email: Pzumbansen@osgoode.yorku.ca 


\title{
Law's Knowledge and Law's Effectiveness: Reflections from Legal Sociology and Legal Theory
}

\author{
Peer Zumbansen ${ }^{*}$
}

\section{A. Sociological VIEWPOINTS ON LEGal SOCIOLOGY ${ }^{\dagger}$}

With considerable regularity, the established and functioning scientific apparatus is able to reshape itself, to confirm or change its course and the respective lenses of observation through the rationalization of themes, trends and through the identification of individuals and groups of scholars who are being associated with these developments. This exercise, leaving its traces in conferences, edited volumes and the formation of scientific associations, is largely centred around the formulation, assessment and defence of scholarly projects and tasks. The importance of such undertakings lies, however, in their ability to never let the forces of institutionalization, formalization and bureaucratization take the upper hand over the continuing diversity and curiosity that reigns beneath their surface. The awarding of academic honours and prizes themselves are part of the institutionalization of scholarly projects, but they come with the calming realization that, despite all the festivity, it is clear to everyone that there is no one who deserves the prize. There is in fact no prize recipient. What remains is the constantly nagging doubt whether curiosity and critical inquiry still govern our search, whether ears and eyes continue to be open.

The following observations focus on a number of well-known and recently emerging research challenges to the sociology of law. In this undertaking I am served by two reference points, one being the state, the other one being the market. The protagonists are Michael Kumpfmüller and Josef Ackermann, but also Theodor Baums. We are reading Kumpfmüller -the Berlin based novelist, the author and creator of Hampels Fluchten, ${ }^{1}$, Durst ${ }^{2}$ and the recently published novel Nachricht an Alle ${ }^{3}$-, because his themes are those of legal sociology. Particularly in Durst and

\footnotetext{
* Prof. Dr. LL.M. (Harv.), lic. en dr. (Paris), Osgoode Hall Law School, York University, Toronto, Canada. Canada Research Chair in the Transnational and Comparative Law of Corporate Governance. Associate Dean Research and Director, Critical Research Laboratory in Law \& Society (www.criticalresearchlab.org). Email: Pzumbansen@osgoode.yorku.ca.

† The paper is based on the author's recipient lecture for the 2008 Law \& Society Prize of the German-language Legal Sociology Association, awarded by the Christa-Hoffmann-Riem-Foundation on 5 September 2008 at the University of Lucerne, Switzerland. The Laudatio lecture was presented by Marc Amstutz (Université de Fribourg, Switzerland). The Laudatio and a shorter version of this paper are printed - in German - in 28 ZEITSCHRIFT FÜR RECHTSSOZIOLOGIE, 279-280 and 281-294 respectively. This Lecture is dedicated to Karl-Heinz Ladeur to his $65^{\text {th }}$ birthday. The author is grateful to Sujith Xavier for helpful comments.

${ }^{1}$ Michael KumpFmüLler, Hampels Fluchten (2002)

${ }^{2}$ Michael KumpFMÜLleR, DuRst (2003)

${ }^{3}$ Michael KUMPFMÜLLER, NACHRICHT AN ALle (2008)
} 
Nachricht, the author succeeds in providing us with an immensely poignant and inspiring view on the methodological challenges that we confront in our professional attempts at positioning the law today within and beyond the nation state. Another figure, well worthy of our attention is Theodor Baums, a banking and corporate law professor at Johann Wolfgang Goethe-University in Frankfurt, who some years ago presided over a governmental expert commission on Corporate Governance. ${ }^{4}$ Finally, then, we are well advised to consider Josef Ackermann, the Swiss-born banker who since 2002 has been leading the Deutsche Bank in Frankfurt. The study of these personalities promises a number of lessons about the development of the market, its relation to the state and the role of the law.

\section{B. LAW'S EFFECTIVENESS: COMPARATIVE GLIMPSES}

State and Market, Kumpfmüller, Baums and Ackermann: the central legal-sociological question raised in this constellation is about the effectiveness of law. This well-known question ${ }^{5}$ remains of great importance still today. ${ }^{6}$ And yet, the sheer wealth of scientific research and methodological contestation surrounding the issue of law's effectiveness only underscores the distance between scholarly innovation and the current, far-reaching absence of legal sociological work in today's law school curricula. In spite of an arduous production of scholarship and discourse at symposia, roundtables and dedicated research centres in legal sociology ${ }^{7}$, the field appears esoteric and, at best, irrelevant to today's law students in dire need of 'skill training' and practical instruction. ${ }^{8}$ In the current climate, there is indeed little reason to think, expect and even less to hope that most law students at the time of graduation would have had a meaningful exposure to legal sociological investigations of the sources of law, the effectiveness and the contested boundaries of law: ${ }^{9}$ along with philosophy of law, legal theory and legal history, the sociology of law is among the very rarely found fields of instruction in contemporary legal curricula.

\footnotetext{
${ }^{4}$ Theodor Baums, Empfiehlt sich eine Neuregelung des aktienrechtlichen Anfechtungs- und Organhaftungsrechts, insbesondere der Klagemöglichkeiten von Aktionären?, GUTACHTEN VOR DEM 63. DEUTSCHEN JURISTENTAG IN LEIPZIG, Leipzig, DJT (2000) ; Theodor Baums, Interview: Reforming German Corporate Governance: Inside a Law Making Process of a very new nature, 2 GERMAN LAW JOURNAL at: http://www.germanlawjournal.com/past_issues.php? id=43 (2001).

${ }^{5}$ Manfred Rehbinder/Helmut Schelsky (Ed.), Zur EFFEKTIVITÄT DES RECHTS, 1972.

${ }^{6}$,Wie Wirkt Recht?' Interdisziplinäre Rechtsforschung zwischen Rechtswirklichkeit, Rechtsanalyse und Rechtsgestaltung. 1. Congress of the German-language Associations in Legal Sociology (Germany - Austria Switzerland) 4-6 September 2008, University of Lucerne.

${ }^{7} \mathrm{http}: / /$ www.isa-sociology.org/rc12_sociolegal.htm

${ }^{8}$ See, for example, http://legalscholarshipblog.com/2008/12/08/technology-ethics-and-the-practice-of-law-trainingthe-21st-century-law-student-san-diego-2/; see also the recently reformed third-year program at Washington \& Lee University School of Law, focusing entirely on practical instruction, contract drafting and mediation: http://law.wlu.edu/thirdyear/

${ }^{9}$ See for example, the contemplation by Danny Priel, Boundaries of Law and the Purpose of Legal Philosophy, Law and Philosophy 2008/2009, available at http://ssrn.com/abstract=1086389.
} 
In 1935, Karl Llewellyn voiced an elaborate critique against himself and his colleagues for having only the faintest clue of what it was they were really teaching their students, given that they had no understanding of the legal practice students were entering after graduation. ${ }^{10}$ It was a challenging path that Llewellyn and some of his contemporaries had been embarking on, a path that would take them towards a more solid engagement in their research with empirical data ${ }^{11}$ on the one hand, and while pursuing a relentless demystification of legal formalism on the other. ${ }^{12}$ Retrospectively, we might say that the Realists' engagement and critique eventually unfolded in a considerable normalization - "We are all Realists now ${ }^{\text {"13 }}$. But we are also advised to remain mindful how Legal Realism had to struggle with the polemical critique that posited that the Realists' embrace of empiricism had allegedly led them to hold crude, theory-bare reality views. This tension that unfolded around a number of heated exchanges ${ }^{14}$ is (we should underline however), only too reflective of the field's ambitious endeavour: the ongoing methodological inquiries into the foundations and orientations of legal sociological work are a strong testimony of the fact that legal sociology, much like any other 'foundational' field in law, continues to evolve. $^{15}$

This perspective on the evolution of legal realism and 'law and society' in the Anglo-American and Anglo-Saxon context finds important correlatives in Western Europe: the Western Welfare State made extremely ambitious demands of the legal system, the lawyers in the legislature, the judiciary and the administrations required sensibility to a constantly changing legal reality. ${ }^{16}$ It is no surprise that the realization "We are all Realists" is uttered today in a state of considerable exhaustion and sobriety. Acutely, Habermas in the mid-1980s observed a crisis of the Welfare

${ }^{10}$ Karl Llewellyn, On What is Wrong With So-Called Legal Education, 35 COLUMBIA LAW REVIEW 651 (1935)

11 Karl N. Llewellyn \& Edward Adamson Hoebel, The Cheyenne Way: Conflict And CASE Law IN Primitive Jurisprudence (1941); see also JOHN HENRY SCHLEGEl, AMERICAN LEGAL REALISM AND EMPIRICAL Social SCIENCE (1995); Neil Duxbury, Legal Realism for Legal Realists, 9 RATIO JURIS 198 (2007).

12 Karl Llewellyn, A Realistic Jurisprudence: The Next Step, 30 ColumbIA L. ReV. 431-475 (1930); Karl Llewellyn, Some Realism about Realism, 44 HARVARD LAW REVIEW 1222 (1931).

${ }^{13}$ Joseph W. Singer, Legal Realism Now, 76 CALIFORNIA LAW REVIEW 465 (1988): 465, 467.

${ }^{14}$ Roscoe Pound, The Call for a 'Realist' Jurisprudence, 44 HARV. L. REV. 706 (1931); Llewellyn, 1930, 1931, supra note?

${ }^{15}$ See, for example, Richard A. Posner, Social Norms, Social Meaning, and the Economic Analysis of Law, 27 J. Legal Studies 553 (1998); David Nelken/Johannes Feest (Ed.), AdAPTING Legal Cultures, 2001; Roger Cotterell, Sociological Perspectives on Law (2001); Brian Z. TAMAnaha, A General Jurisprudence of LAW AND SOCIETY (2001); HANS-Albrecht HesSE, EINFÜHRUNG IN DIE RECHTSSOZIOLOGIE (2004); THOMAS Raiser, Grundlagen der Rechtssoziologie, 4. Aufl. (2007); Manfred Rehbinder, Rechtssoziologie, 6. Aufl. (2007).

${ }^{16}$ Niklas Luhmann, Political Theory in the Welfare State [1981, transl. by John Bednarz Jr.] (1990); Peer Zumbansen, Law After the Welfare State: Formalism, Functionalism and the Ironic Turn of Reflexive Law, 56 AM. J. COMP. L. 769 (2008). 
State and the exhaustion of utopian energies. ${ }^{17}$ And as such, it comes as no surprise that the efforts made towards a resurrection of legal sociology occurred during the last days of the Welfare State, that had once so ambitiously entered the stage of legal, political, economic and social regulation. Its emergence is intimately connected to the questions surrounding the fate and prospects of law. In the European context, this question was neither asked nor was an answer attempted without a reference to the state. ${ }^{18}$ The welfare state differed from the social state in that it no longer merely sought to identify and to respond to 'social problems' but instead set out to resolve them as part of a comprehensive mandate of social engineering. ${ }^{19}$ Today, predominantly under the pressure of the transnationalization of human affairs, the law-state nexus has become extremely porous and contested, something that legal sociologists had certainly extrapolated already a long time ago. ${ }^{20}$ Then and now, law is apparently caught between either claiming its autonomous nature or by incessantly constructing its character through a historically informed reflection on the ebbs and flows of social regulation and stateoriginating legal intervention. ${ }^{21}$ It is this champ de travail that opens in the late 1970s and early 1980s in Europe and from which many long-lasting impulses will emanate into, for example, present day discussions around delegated powers and the legitimacy of private ordering. ${ }^{22}$

While the emerging concepts of "procedural" 23 and "reflexive law",24 in German legal theoretical and sociological debates and of "responsive law" in the U.S ${ }^{25}$ discourse share some overlapping

\footnotetext{
17 Jürgen Habermas, The New Obscurity: The Crisis of the Welfare State and the Exhaustion of Utopian Energies [1985], in: The New Conservatism. Cultural Criticism and the Historians' Debate [ed. and transl. by Shierry Weber Nicholsen] 48 (Habermas Ed. 1989).

18 Gralf-Peter Calliess, Prozedurales Recht (1999); Peer Zumbansen, OrdnungSMuster Im Modernen WohlfahrtsstaAt. Lernerfahrungen ZWischen StaAt, Gesellschaft und Vertrag (2000); Christoph MÖllers, StaAt ALS ARgument (2000).

${ }^{19}$ Niklas Luhmann, Politische Theorie im WohlfahrtsstaAt (1981); Niklas Luhmann, Metamorphosen des

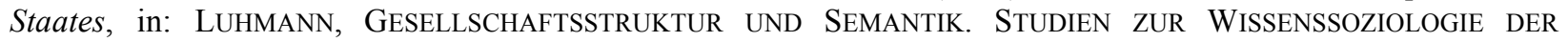
MODERNEN GESELLSCHAFT 101 (1995).

20 Eugen Ehrlich, Fundamental Principles of the Sociology OF LAW (orig. published in German as Grundlegung der Soziologie des Rechts, 1913) (1962).

${ }^{21}$ Rudolf Wiethölter, Die Wirtschaftspraxis als Rechtsquelle, in: Das Rechtswesen - Lenker oder Spiegel der Gesellschaft? 165 (Bockelmann Ed. 1971); Rudolf Wiethölter, Privatrecht als Gesellschaftstheorie?, in: FunKtionswANDEL DER PRIVATRECHTSINSTITUTIONEN. FESTSCHRIFT FÜR LUDWIG RAISER ZUM 70. GEBURTSTAG 645 (Baur/Esser/Kübler/Steindorff Ed. 1974); Karl-Heinz Ladeur, Gesetzesinterpretation, 'Richterrecht' und Konventionsbildung in kognitivistischer Perspektive: Handeln unter Ungewissheitsbedingungen und richterliches Entscheiden, 77 ARCHIV FÜR RECHTS- UND SOZIALPHILOSOPHIE 176 (1981); Gunther Teubner, Reflexives Recht, 68 ARSP 13 (1982) (engl.: Gunther Teubner, Substantive and Reflexive Elements in Modern Law, 17 LAW AND SOCIETY REVIEW 239 (1983)].

22 See, for example, Gregor Bachmann, Private Ordnung (2006); Johannes Köndgen, Privatisierung des Rechts. Private Governance zwischen Deregulierung und Rekonstitutionalisierung, 206 ACP 477 (2006).

23 Rudolf Wiethölter, Proceduralization of the Category of Law, in: CRITICAL LEGAL THOUGHT: AN AMERICANGERMAN DEBATE 501 (Joerges/Trubek Ed. 1985); CALliESS (1999), supra.

${ }^{24}$ Gunther Teubner, Substantive and Reflexive Elements in Modern Law, 17 LAW AND SOCIETY REVIEW 239 (1983).
} 
concerns regarding both law's effectiveness and boundaries. ${ }^{26}$ Their ensuing trajectories appear to have proceeded in less parallel fashion. German legal theorists and sociologists appeared to have worked in the wake of Weber's observation that 'the world is disenchanted'27, and from then on the progression of legal thought had to move through a brief but ardent positivism $\mathrm{v}$. natural law-debate after the $\mathrm{War}^{28}$ on to Rule-of-Law v. Social/Welfare State-discussions in the $1950 \mathrm{~s}$ and $1960 \mathrm{~s}^{29}$ onwards to numerous differentiations of legal regulation in a powerfully unfolding pluralistic, post-industrial society. ${ }^{30}$ In face of this breath-taking evolution of law as an integral part of political, social and economic change, it could ever less be understood as a metaprogram deriving its legitimacy from a comprehensive and unified normative framework, but instead as one among other contestable rationality forms in society. Nowhere has this argument been put forward in more radical fashion than in Niklas Luhmann's early sociology of law, spelling out in nuce the research program and the concept of society in Systems Theory. ${ }^{31}$ Standing on systems theoretical grounds, the concept of reflexive lawthat historically emerged during an important and challenging period unfolding between 1968 and the end of the socialliberal coalition in Bonn with an ardent debate about West German identity, international security politics, U.S.-German relations erupting around the stationing of Pershing and Cruise Missile rockets in Germany by U.S. military in the early 1980s, early on confronted a number of substantive critiques. The range of these contestations included, from the left, the recognition of the concept as representing an anti-emancipatory affirmation of the status quo ${ }^{32}$ to, in theoretical terms, the contention of reflexive law rendering a soft and not sufficiently stringent application

\footnotetext{
${ }^{25}$ Philip SELZNICK, LAW, SOCIETY, AND INDUSTRIAL JUSTICE (1969).

${ }^{26}$ David Trubek, Max Weber on Law and the Rise of Capitalism, WISC. L. REV. 720 (1972); Teubner (1983), supra; Rudolf Wiethölter, Social Science Models in Economic Law, in: CONTRACT AND ORGANISATION. LEGAL ANALYSIS IN THE LIGHT OF ECONOMIC AND SOCIAL THEORY 52 (Daintith/Teubner Ed. 1986).
}

${ }^{27}$ Weber, Science as Vocation, in: From MAX WeBER: EsSAYS IN SOCIOLOGY (H.H. Gerth and C. Wright Mills, translated and ed., 1946), 129-156, available online http://www.ims.demokritos.gr/people/tbou/Weber_Science_as_Vocation.pdf

${ }^{28}$ Gustav Radbruch, Gesetzliches Unrecht und übergesetzliches Recht, 1 SJZ 105 (1946); Stanley L. Paulson, On the Background and Significance of Gustav Radbruch's Post-War Papers, 26 OXFORD JOURNAL OF LEGAL STUDIES 17 (2006).

${ }^{29}$ On the one hand: Ernst Forsthoff, Begriff und Wesen des sozialen Rechtsstaates, 12 VERÖFFENTLICHUNGEN DER Vereinigungen Der Deutschen StAATSRECHTSLEHRER 8 (1954); on the other: Rudolf Wiethölter, Die Position des Wirtschaftsrechts im sozialen Rechtsstaat, in: WIRTSCHAFTSORDNUNG UND RECHTSORDNUNG, FESTSCHRIFT FÜR FRANZ BÖHM ZUM 70. GEBURTSTAG 41 (Coing/Kronstein/Mestmäcker Ed. 1965).

30 Dieter Grimm, Reformalisierung des Rechtsstaatsprinzips als Demokratiepostulat, 20 JURISTISCHE SCHULUNG [JuS] 704 (1980); Rüdiger Voigt (Ed.), VERRECHTLICHUNG, 1980.

31 Niklas Luhmann, Rechtssoziologie (1980), 3. Aufl. (1987) [Engl.: Niklas Luhmann, A Sociological THEORY OF LAW (1985)].

32 Joachim Nocke, Autopoiesis - Rechtssoziologie in seltsamen Schleifen, 19 KJ 363 (1986); Ingeborg Maus, Perspektiven "reflexiven Rechts" im Kontext gegenwärtiger Deregulierungstendenzen, 19 KJ 390 (1986); Erhard Blankenburg, The Poverty of Evolutionism: a critique of Teubner's case for 'reflexive law', 18 LAW \& SOCIETY REV. 273 (1984). 
of the theory of autopoiesis to the field of law. ${ }^{33}$ As governance challenges continued to accrue under the pressure of Europeanization ${ }^{34}$ and Internationalization ${ }^{35}$ of a fast-evolving postindustrial society, this was reflected in an intensification of legal theoretical and legal sociological work altogether showing a continuous expansion of legal imagination beyond a traditional state-based doctrinal focus towards ambitiously interdisciplinary deconstructions of law's boundaries. ${ }^{36}$

In the U.S., this process remained less tarnished by imminent pressures on its political sovereignty understanding that would compare to those facing the $\mathrm{EC}^{37}$ and, eventually, EU member states. Legal debates have long been characterized by the tandem of pronounced battles over civil liberties on the one hand and federalism on the other - often times almost indistinguishably so. ${ }^{38}$ Seen through the lens of power struggles, identified under a lens of separation of powers or, to a pluralistic diverse society, assessments of the effectiveness of law

${ }^{33}$ Niklas Luhmann, Einige Probleme mit "reflexivem Recht", 6 ZEITSCHRIFT FÜR RECHTSSOZIOLOGIE 1 (1985); Niklas Luhmann, Some Problems with Reflexive Law, in: STATE, LAW AND ECONOMY AS AUTOPOIETIC Systems 389 (Teubner/Febbrajo Ed. 1992); for reflections on Teubner's influence on legal theory, see the contributions to Gralf-Peter Calliess/Andreas Fischer-Lescano/Dan Wielsch/Peer Zumbansen (Ed.), SozIOLOGISCHE JurisprudenZ. FESTSCHRIFT FÜR GUNTHER TEUBNER ZUM 65. GEBURTSTAG, 2009

${ }^{34}$ See generally: KARL-HeInZ NARJES, DIE EuROPÄISIERUNG DES RECHTS (1987); Hans-Werner Rengeling (Ed.), EUROPÄISIERUNG DES RECHTS: RINGVORLESUNG ANLÄßLICH DES ZEHNJÄHRIGEN BESTEHENS DES INSTITUTS FÜR EUROPARECHT DER UNIVERSITÄT OSNABRÜCK 1995, 1996; for public law: VOLKER BOEHME-NEßLER, EUROPÄISCHES RICHTLINIENRECHT WANDELT DEUTSCHES VERWALTUNGSRECHT: EIN BEITRAG ZUR EUROPÄISIERUNG DES DEUTSCHEN RECHTS (1994); see the deliberations at the annual conventions of the Vereinigung der Deutschen Staatsrechtslehrer, for example: FÖDERALISMUS ALS NATIONALES UND INTERNATIONALES ORDNUNGSPRINZIP (1962); BEWAHRUNG UND VERÄNDERUNG DEMOKRATISCHER UND RECHTSSTAATLICHER VERFASSUNGSSTRUKTUR IN DEN INTERNATIONALEN GEMEINSCHAFTEN (1964); DER VERFASSUNGSSTAAT IM GEFLECHT DER INTERNATIONALEN BEZIEHUNGen (1977); DeR VERFASSUngSSTAAT ALS GLIED EINER EUROPÄISCHEN GEMEINSCHAFT (1991); for private law see, for example, Christoph Weber (Ed.), EUROPÄISIERUNG DES PRIVATRECHTS: ZWISCHENBILANZ UND Perspektiven. Mainzer Tagung, $10-13$ SePtember 1997 Der Gesellschaft Junger ZiVILRECHTSWISSENSCHAFTLER, 1997; Gert BRÜGGEMEIER, HAFTUNGSRECHT: StRUKTUR, PRINZIPIEN, SCHUtZBEREICH: EIN BeITRAg ZUR EUROPÄISIERUNG DES PRIVATREChts (2006); Christian Joerges, The Challenges of Europeanization in the Realm of Private Law: A Plea for a New Legal Discipline, 14 DuKE J. CoMP. \& INT'L L. 149 (2004).

${ }^{35}$ STEPHAN HOBE, DER OFFENE VERFASSUNGSSTAAT ZWISCHEN SOUVERÄNITÄT UND INTERDEPENDENZ: EINE STUDIE ZUR WANDLUNG DES STAATSBEGRIFFS DER DEUTSCHSPRACHIGEN STAATSLEHRE IM KONTEXT INTERNATIONALER institutionalisierter KoOperation (1998); Udo Di FABio, DAS ReCht OFFENER STAATEN (1998); Udo Di FABIO, DER VERFASSUNGSSTAAT IN DER WELTGESELLSCHAFT (2001).

36 Karl-Heinz Ladeur, Gesetzesinterpretation, "Richterrecht" und Konventionsbildung in kognitivistischer Perspektive, 77 ARCHIV FÜr RECHTS- UND SOZIALPHILOSOPHIE 176 (1991); KARL-HEINZ LADEUR, POSTMOdERNE RECHTSTHEORIE (1992); KARL-HeINZ LADEUR, DAS UMWELTRECHT DER WiSSENSGESELLSCHAFT (1995).

${ }^{37}$ See only Joseph H.H. Weiler, The Transformation of Europe, YALE LAW JOURNAL 2403 (1991).

${ }^{38}$ Brown v. Board of Education of Topeka, 347 U.S. 483 (1954); Bowers v. Hardwick, 478 U.S. 186 (1986); Romer v. Evans, 517 U.S. 620 (1996); Lawrence v. Texas, 539 U.S. 558 (2003). 
circled around matters of access to justice ${ }^{39}$, issues of equality, distribution, and identity ${ }^{40}$ or the transformation of the political-legal system. ${ }^{41}$

Here and there, not least under the impression of persistently mobilized claims by legal sociologists, anthropologists and theorists regarding the importance of disentangling the legal system from either pre-existing or alternative modes of social ordering ${ }^{42}$, legal doctrine eventually began to embrace concepts of law developed neither out of the authority of the state nor on the grounds of a coherent normative framework. ${ }^{43}$ Many of the German anxieties about the failure of the Welfare State did not directly echo in the U.S., where the debate continued to evolve more around the tension between form (rules) and substance (standards), boiling down in the end to the question whether it should be in the judge's discretion to make law. ${ }^{44}$ In 1976 , Duncan Kennedy noted: "[T]he social engineering approach has not produced convincing results beyond the confines of particular fields. Generalizations that at first seem highly plausible turn out on further examination to be false, or at least no more convincing than diametrically opposed counter principles." While more recent iterations of such contestations only rarely make references to 'legal pluralism', they either tend to take on specialized arenas of social-legal theory $^{46}$ or continue to confront hard lines in established areas. ${ }^{47}$ Characterizing the

\footnotetext{
${ }^{39}$ Marc Galanter, Why the 'Haves' Come Out Ahead: Speculations on the Limits of Legal Change, 9 LAW \& SOCIETY REV. 95 (1974).

${ }^{40}$ On the one hand: Richard A. Posner, Economic Analysis of Law (1973); on the other: Duncan Kennedy, Distributive and Paternalist Motives in Contract and Tort Law, with Special Reference to Compulsory Terms and Unequal Bargaining Power, 41 Maryland L. ReV. 563 (1982); Carole Pateman, The Patriarchal Welfare State, in: Democracy AND THE Welfare StATE 231 (Gutman Ed. 1988), onwards to IRIS MARION Young, JustiCE AND THE Politics of Difference (1990), and Elizabeth Frazer/Nicola LACEy, The Politics of Community. A FEMINIST CRITIQUE OF THE LIBERAL-COMMUNITARIAN DEBATE (1993).

${ }^{41}$ Richard B. Stewart, The Discontents of Legalism: Interest Group Relations in Administrative Regulation, 1985 Wisc. L. REV. 655 (1985); Chevron U.S.A., Inc. v. Natural Resources Defense Council, Inc., 467 US 837 (1984); Jody Freeman, The Contracting State, 28 Fla. St. U.L. Rev 155 (2000); Orly Lobel, The Paradox of Extralegal Activism: Critical Legal Consciousness and Transformative Politics, 120 HARV. L. REV. 937 (2007).

${ }^{42}$ Sally Falk Moore, Law and Social Change: the semi-autonomous field as an appropriate subject of study, 7 LAW \& Society ReVIEW 719 (1973); Sally Engle Merry, Legal Pluralism, 22 LAW \& SocIETY REVIEW 869 (1988); Marc Galanter, Justice in many rooms: Courts, Private Ordering and Indigenous Law, 19 J. LEG. PLURALISM 1 (1981).

${ }^{43}$ Then: Rudolf Wiethölter, Artikel Bürgerliches Recht, in: HANDLEXIKON ZUR RECHTSWISSENSCHAFT 47 (Görlitz Ed. 1972); Rudolf Wiethölter, Begriffs- oder Interessenjurisprudenz - falsche Fronten im IPR und Wirtschaftsverfassungsrecht, in: INTERNATIONALES PRIVATRECHT UND RECHTSVERGLEICHUNG IM AUSGANG DES 20. JAHRHUNDERTS 213 (Lüderitz/Schröder Ed. 1977); Today: KARL-HEINZ LADEUR, POSTMODERnE RECHTSTHEORIE (1992); KARl-Heinz Ladeur, Das Umweltrecht der Wissensgesellschaft (1995); Karl-Heinz Ladeur, Die Prozeduralisierung des Unternehmens, in: PRIVATRECHT IM "RISIKOSTAAT" 137 (Hart Ed. 1997).

${ }^{44}$ Probably one of the best analysis of the form-substance distinction has been provided by Duncan Kennedy, Form and Substance in Private Law Adjudication, 89 HARV. L. REV. 1685 (1976).

${ }^{45}$ Id., at 1704.

${ }^{46}$ See, for example, the work in legal geography by Nicholas Blomley, Landscapes of Property, in: THE LEGAL GeOgraphies ReAder. LAw, Power, AND SpACE 118 (Blomley/Delaney/Ford Ed. 2001), and Richard Ford, Law's
} 
contemporary debate, in slightly more accentuated form in the U.S. than in Germany, is a particular polarization of political and theoretical camps. ${ }^{48}$ An extremely prolific legal theoretical and political debate has thus grown out of the post-Realist Critical Legal Studies movement with its soon following differentiations into Feminist Legal Studies and Critical Race Theory, into Post-Colonial Studies, 'Third World Approaches to International Law' [TWAIL] and critical public international law developing in parallel with an immensely influential 'prairie fire' of the "Law \& Economics" school. Indeed, as with the force of a prairie fire ${ }^{49}$ its adepts have taken charge of law school posts, judicial benches and curricula.

\section{LAW'S SOBRIETY}

These legal theoretical and legal sociological efforts to think of 'alternatives to law' are intimately tied to a search for 'alternative' law. ${ }^{50}$ This, however, suggests an ability of doing things differently, of finding recognizable discernable solutions, instead of dismissing the project of legal regulation as futile from the start. Critical, political, alternative theories of law, then, have long been dealing with the polemical observation that they lack stringency and coherence, which makes them - due to their missive doctrinal solidity - eventually impractical. Not a nice situation! Even less, when it turns out that - extreme cases aside - despite an alternative, perhaps with a richer reasoning the case's outcome would not necessarily always have to be a different one. ${ }^{51}$ Yet, those who believe that courts are either overburdened with cases, or that courts have neither the time nor the competence to adjudicate cases arising out of complex transactions, are

Territory (A History of Jurisdiction), 97 Michigan LAW REVIEW 843 (1999), or local government law: Gerald Frug, The City as a Legal Concept, 93 HARV. L. REV. 1057 (1980).

${ }^{47}$ E.g., for corporate law: William W. Bratton, Welfare, Dialectic, and Mediation in Corporate Law, 2 BerKELEY Bus. L.J. 59 (2005); Lawrence E: Mitchell, The Speculation Economy. How Finance Triumphed over InDUSTRY (2007); for contract law: Roy Kreitner, Fear of Contract, 2004 WISC. L. REV. 429 (2004); RoY Kreitner, Calculating Promises. The Emergence of Modern American Contract Doctrine (2007); see also contributions in Symposium Issue "Governing Contracts: PubliC and Private Dimensions", 14 Ind. J. GLOB. LEG. STUD. 181-481 (2007) [Zumbansen, Guest Ed.]

${ }^{48}$ Thus the ones: PhILIP SELZNICK, LAw, SOCIETY, AND INDUSTRIAL JUSTICE (1969); Marc Galanter, Why the 'Haves' Come Out Ahead: Speculations on the Limits of Legal Change, 9 LAW \& SOCIETY REV. 95 (1974); so the others: Guido Calabresi, The Cost of Accidents. A Legal and EConomic ANAlysis (1970); Richard A. Posner, ECONOMIC ANALYSIS OF LAW (1973). In retrospective perspective today: Duncan Kennedy, Three Globalizations of Law and Legal Thought: 1850-2000, in: THE New LAW AND ECONOMIC DEVELOPMENT 19 (Trubek/Santos Ed. 2006); poignantly provocative today: ERIC A. POSNER, LAW AND SOCIAL NORMS (2000).

${ }^{49}$ Brian R. Cheffins, Corporations, in: The OXford HANDBook of Legal Studies 485 (Cane/Tushnet Ed. 2003).

50 Then: Erhard Blankenburg/Ekkehard Klausa/Hubert Rottleuthner/Ralf Rogowski (Ed.), AlterNATIVE ReChtSFormen und Alternativen zum Recht, 1980; Robert C. Ellickson, Order without LaW: How Neighbors SetTle Disputes (1991); Today: Sally Engle Merry, New Legal Realism and the Ethnography of Transnational Law, 31 LAW \& SOC. INQUIRY 975 (2006); John N. Drobak (Ed.), NORMS AND THE LAW, 2006.

51 Rudolf Wiethölter, Zur Argumentation im Recht: Entscheidungsfolgen als Rechtsgründe?, in: ENTSCHEIDUNGSFOLGEN ALS RECHTSGRÜNDE 89 (Teubner Ed. 1995). 
likely to question whether anybody should be engaging in such scientific expounding of law and the politics of adjudication at all.

Law as the labour of Sisyphus on the legal paradox could just possibly subside in purely pragmatic fashion, making room for common sense assessments of the solutions that situations call for. Such pragmatic, neo-formalistic approaches, however, stand in stark contrast to the depth and breadth of legal deconstructivist, legal sociological and theoretical insights gained over the last decades. Centrally, the currently dominating (neo-) formalist and (neo-)functionalist critique of adjudication hopes to make invisible the fact that underneath each legal case lies a social conflict, a real story, a human fate that the law must inevitably transgress and alienate in order to address it as a 'legal' issue. ${ }^{52}$ Yet, it has long been clear that such abstraction will inevitably turn into 'nonsense' where its artificial nature is denied. ${ }^{53}$ Thus, on both sides of the political spectrum, citizens doubt and despair over law, finding it not to be 'on top of the times' ${ }^{54}$ But now, what? The economistic dismissal of law in the name of social self-regulation and market ordering that has been marking the last two decades, can easily be seen to make the same mistakes that legal formalism was guilty of some one hundred years ago. By relying on terminology to capture what in fact are deep-running, irreconcilable differences and conflicts, these scholars suggest that law should be substituted by 'social norms' ${ }^{55}$ Legal pluralism then, social norms now? Only, with different politics? ${ }^{56}$ Legal theory and legal sociology can only hope to make sense of this paradox by repositioning the question as to how these social norms differ from law as to one about why this distinction matters.

On the political right, law is being purified, detached and neutralized because it is being held accountable for not being able to adequately respond to the hyperbolic demands of a complex, globally spanning market society. Somewhere on the left, law is still understood as a sticky substance that attaches itself to the course of the world as an empowering reminder of unattained business, of unfulfilled or repeatedly shattered hopes, of exclusion and exploitation. Given that law protects expectations through its formalized operationable structure, it tracks and records patterns of hope, experience and decisions. But on both sides, Weber's disenchanted world fuses

52 Gunther Teubner, Dealing With Paradoxes: Luhmann, Wiethölter, Derrida, in: PARADOXES AND INCONSISTENCIES IN LAW 41 (Perez/Teubner Ed. 2006); Gunther Teubner/Peer Zumbansen, Rechtsentfremdungen: Zum gesellschaftlichen Mehrwert des zwölften Kamels, 21 ZEITSCHRIFT FÜR RECHTSSOZIOLOGIE 189 (2000).

${ }^{53}$ See already the critique by Felix Cohen, Transcendental Nonsense and the Functional Approach, 35 COLUMBIA LAW REVIEW 809 (1935).

${ }^{54}$ Rudolf Wiethölter, Die Wirtschaftspraxis als Rechtsquelle, in: DAS RECHTSWESEN - LENKER ODER SPIEGEL DER GESELlsCHAFT? 165 (Bockelmann Ed. 1971), S. 170.

${ }^{55}$ Robert E. Scott, The Death of Contract Law, 54 UTLJ 369 (2004); ERIC A. PosNER, LAW AND SOCIAL NormS (2000); see the brilliant discussion of earlier work in this field by David Charny, Illusions of a Spontaneous Order: 'Norms' in Contractual Relationships, 144 U. PA. L. ReV. 1841 (1996); Stewart Macaulay, Relational Contracts Floating on a Sea of Custom? Thoughts about the Ideas of Ian Macneil and Lisa Bernstein, 94 Nw. U. L. REV. 775 (2000).

${ }^{56}$ For a much needed reflection, see Pierre Schlag, Spam Jurisprudence, Air Law, and the Rank Anxiety of Nothing Happening (A Report on the State of the Art), 97 GeORGETOWn L.J. 803 (2009), 804-807, 816-821. 
into the legitimation crisis ${ }^{57}$ onwards into the eventually dawning post-modern realization of the centrality and fragility of knowledge. ${ }^{58}$ On the left, attempts are made to save law, either as procedural framework for societal deliberation ${ }^{59}$, a civil culture of disputes ${ }^{60}$ or in defence against its one-sided appropriation. ${ }^{61}$ It is against the paradox of the congruent methodologies of approaching the difference between law and non-law described above that today we deal with the uncertainty over the political orientations - their progressive or conservative nature - of projects such as those focusing on the 'experimental society', the 'post-modern state' ${ }^{62}$, or the 'global Bukowina' with law caught up in transnational regime collisions. ${ }^{63}$ This is likely not a productive or appropriate line of questioning. The depiction of law as a social system with a particular rationality points to an altogether more complex and more problematic relationship between law and social reform projects that wish to instrumentalize law for their purposes.

Today, we are all 'Realists' to the degree that we have learned to look skeptically at law's abstractions and its alleged purity. But, we have also all become 'Economists', maybe more so: realizing the degree to which law in the process of Weber's rationalistic disenchantment of the world and in Forsthoff's neutralization of the industrial society ${ }^{64}$ has been depicted as a 'serving' one. ${ }^{65} \mathrm{We}$ are indeed hard-pressed to accept the continuing and dominating force of economic rationality over other societal rationalities. When Rudolf Wiethölter in 1971 asked his audience to reflect on the way in which we might understand economic practice as a source of law, he did

\footnotetext{
${ }^{57}$ JÜRGEN HABERMAS, LEGITIMATION CRISIS [orig. German 1973: Legitimationskrise im Spätkapitalismus] (1975).

${ }^{58}$ Jean-Francois Lyotard, The Postmodern Condition: A Report on KNOWLedge [orig. French: La condition postmoderne, Éditions de Minuit, Paris 1979] (1984), 6.

59 JÜrgen Habermas, Faktizität und Geltung. Beiträge zUR Diskurstheorie Des Rechts UND DES DEMOKRATISCHEN RECHTSSTAATS (1992) [Engl.: Jürgen Habermas, Between Facts and Norms [transl. William Rehg] (1996)].

60 Günter Frankenberg, Die Verfassung Der Republik. Autorität Und SOlidarität in Der ZIVILGESELLSCHAFT (1996).

${ }^{61}$ Martti Koskenniemi, 'The Lady Doth Protest Too Much'. Kosovo, and the Turn to Ethics in International Law, 65 MODERN LAW REVIEW 159 (2002).

${ }^{62}$ Karl-Heinz Ladeur, Der Staat Gegen die GeSellschaft (2006), Chapter V, A, B.

${ }^{63}$ Andreas Fischer-Lescano/Gunther Teubner, Regime-Collisions: The Vain Search for Legal Unity in the Fragmentation of Global Law, 25 MichigAN J. INT'L L. 999 (2004).

${ }^{64}$ See ERNST ForsthofF, DeR STAAT DER INDUSTRIEGESELLSCHAFT (1971); Ernst Forsthoff, The Administration as Provider of Services (transl. from Der Staat der Daseinsvorsorge, 1938), in: WEIMAR. A JURISPRUDENCE IN CRISIS 326 (Jacobson/Schlink Ed. 2000); for a discussion, see Michael StOlleis, A History OF Public LAW IN GERMANY 1914-1945 (Thomas Dunlop transl.) (2004), 384-387; and PEER ZuMBANSEN, ORDNUNGSMUSTER IM MODERNEN WOHLFAHRTSSTAAT. LERNERFAHRUNGEN ZWISCHEN STAAT, GESELLSCHAFT UND VERTRAG (2000), 93126, and Florian Meinel, Review Essay - Ernst Forsthoff and the Intellectual History of German Administrative Law, 8 GERMAN LAW JOURNAL 785 (2007).

${ }^{65}$ Morton J. Horwitz, The Rise of Legal Formalism, 19 AM. J. LEG. HIST. 251 (1975); Duncan Kennedy, Legal Formality, 2 J. LEG. STUD. 351 (1973); David Trubek, Max Weber on Law and the Rise of Capitalism, WiSC. L. REV. 720 (1972).
} 
so in a particularly challenging manner. ${ }^{66}$ Well aware of the contemporary reliance on economic rationality as governing philosophy and also of the fact that it would take a 30 minutes lecture to convince his friends, but more than a lifetime to convince his enemies, he nevertheless used this opportunity to critically assess the ability of law and legal theory to adequately take into account societal conditions. Critiquing law's crude appropriation of economic thinking, Wiethölter described the world inhabited by law (and by lawyers) as pre-scientific, pre-industrial and predemocratic. Wiethölter found law's (and the lawyers') pitiful condition to be the result partly of its (their) deafness to other scientific voices, the lack of methodological toolkit necessary to confront the challenges of the $21^{\text {st }}$ century as well as its (their) blissfully naïve trust in law being able, somewhere between state and society, to bring about freedom. To speak in this context of economic practice as a source of law, he found to be a call to arms as much as pure nonsense. This assessment resounds strikingly with today's iterations of social norms and their alleged challenge to law. In their oppositional stance, much of the 'law and norms' (sic!) scholarship expresses little interest in what law and norms actually do have in common. ${ }^{67}$

As 'norms' scholars lament, for example, the pitfalls of alleged consumer protectionist or equitydriven adjudication as an expression of an activist judiciary or as inappropriate regulatory intervention, they highlight the promises of social norms, soft law or alternative forms of conflict resolution. This creation of these distinctions, however, prevents them from having to confront the deeply paradoxical nature of 'law' here and ,norms' there. This is regrettable as it severes the ties to a longstanding legal theoretical investigation into the nature of law, which has for a good part of history been an inquiry into the relationship between law and non-law. This history has (should have) taught us that 'law' must inevitably be concerned with the to-and-fro between form and substance, which is nothing else than the existential dispute between law and social norm. Based on these distinctions, we are presented with the choice between state and market, between law and norms, between state 'intervention' and societal self-regulation. This line of argument, however, ignores long-standing Legal Realist insights into the legal nature of markets and the relational nature of rights ${ }^{68}$, insights that are of greatest importance again today where calls for 'more market' or 'tougher regulation' resound strangely out-of-touch with the complex realities of post-Welfare State regulatory regimes.

Where the scholar of systems theory soberly (or, disillusioned?) records the economy's imperialist and hegemonic stronghold over society ${ }^{69}$, the critical legal scholar might wish to

\footnotetext{
${ }^{66}$ Rudolf Wiethölter, Die Wirtschaftspraxis als Rechtsquelle, in: DAS RECHTSWESEN - LENKER ODER SPIEGEL DER GESELLSCHAFT? 165 (Bockelmann Ed. 1971).

${ }^{67}$ Gillian K. Hadfield/Eric Talley, On Public versus Private Provision of Corporate Law, 22 J. LAW, ECON. \& ORG. 414 (2006); critically: Gralf-Peter Calliess/Peer Zumbansen, Rough Consensus and Running Code: A THEORY OF TRANSNATIONAL PRIVATE LAW (forthcoming), 2009.

${ }^{68}$ Robert L. Hale, Coercion and Distribution in a Supposedly Non-Coercive State, 38 PolitiCAL SCIENCE QuARTERLY 470 (1923); Morris R. Cohen, Property and Sovereignty, 13 CORNELl L. Q. 8 (1927).

${ }^{69}$ Gunther Teubner, In the Blind Spot: The Hybridization of Contracting, 8 THEORETICAL INQUIRIES IN LAW 51 (2007).
} 
continue to break this self-fulfilling prophecy. ${ }^{70}$ Eventually, however, both accept the challenge to reach beyond the self-immunization of the market as a given, neutral sphere of human interaction. Yet, while the former is likely to be unhappy, the latter is certain to despair in the face of complex societal, transnational conditions that place a particular sound-barrier before calls for a re-politicization of law. Today's society does not allow for a straight-forward solution to 'problems'. So, what to 'do' now? Read more? Run for office? Buy a motorcycle?

\section{KUMPFMÜLLER'S STATE}

Finally, we turn to Kumpfmüller and Ackermann. In Durst Kumpfmüller reports in bloodchilling soberness how a young single mother one hot summer afternoon abandons her two children in their locked bedroom, with a couple of picnic size juice boxes. The novella, which according to the backcover is based on a true story, tells how the woman spends the next days, how she goes shopping, meets her (abusive) lover and her girl friend, whom she informs that the children are with their grandparents. During these days her thoughts repeatedly recur to the many impressions and reminisces connected to the children, the unrelenting demands of caring for two children, their age-related quarels and their never-ending questions. But, she also thinks of how they might just now be sitting by the window awaiting her return, how they sleep or sit on the floor, drinking juice. The woman in the book entitled Durst (Thurst) is constantly drinking something. Apparently, she is always thursty. What for? A more fulfilled, happier life? A life without having to live with children from two different men in an appartment without much money? A life in which her lover would be sensitive and caring? A life, in which her mother would not equate the absence of a father and husband with the daugther's personal failure? A life, in which her girl friend would not satisfy herself with the answers received, but would prompt the woman to speak about how things really are, the children, life? At the end of the book, the woman returns to the house, sits in the hallway outside her appartment door, where the police found the children to have died of thurst.

What is this book concerned with? What is the law concerned with when addressing this event as a legal case? How can the law know what it needs to know to adequately connect the story in the book with the case it has to solve? Whose failure is it? The mother's, the society's (with the girl friend, the lover, the woman's mother - living in the same appartment building, the neighbors as stand-ins), the state that remains ignorant of all protagonists until it is too late? What does the law know of all this?

Kumpfmüller's Nachricht an alle [News for Everyone], published in 2008, deals with the life of a (fictional) German politician, the Secretary of the Interior, by the name of Selden. Selden holds office in a time after September $11^{\text {th }}$ - i.e. the present. While he is in the U.S. on an official visit, he receives a text message on his cellphone, sent to him by his daugther from a passenger airplne

\footnotetext{
${ }^{70}$ Upendra Baxi, Market Fundamentalisms: Business Ethics at the Altar of Human Rights, 5 Human RigHTS LAW REVIEW 1 (2005).
} 
on the way from Rome to Stockholm. In the message the daughter tells her father that her plane is about to crash. Only much later, indeed after Selden had to speak publicly about the possible causes and relevance of this accident, will it become known that the plane crash did not result from a terrorist attack.

Selden is the Secretary of the Interior of a country with considerable social unrest, with political and economic strikes, a country described as being in a climate of general uncertainty, some of which is likely to result of terrorism-related anxieties. As such, Selden is a familiar, contemporary character. On its face, the account of how Selden absolves one meeting, one press conference after another, raises the reader's question how Selden - as a an office holder or as a private citizen - will deal with his anguish about the loss of his daugther, given that many expect from him an interpretation of the yet unknown causes of the air plane's crash. Will he as Secretary of the Interior argue for the need of heightened security in the face of a terrorist attack? Or, will he continue to carry on as before. And this raises the question when it all began - and when it might end.

Kumpfmüller's account of Selden's actions and thoughts is nothing short of a masterful observation of law's effectiveness. This law is being prepared in ministries, channelled through parliamentary assemblies and implemented. What are the goals that the law pursues? What is the knowledge on which the creation and implemenation of laws is based? Selden's questions, which he ponders while he stares out of the windows of his office, become the questions of the state itself, of the state and its functioning - with or without the law. As such, they are society's questions: Selden's exhaustion in trying to find answers is paralleled by the state's exhaustion in the absence of coherence, of starting and reference points. But, because he is the Secretary of the Interiror, sitting in his office while contemplating his life, he is the state contemplating itself. Selden and the state become artefacts, nodal points of a relentless, never-ending, non-hierarchial knowledge process - echoed in today's administrative science's depiction of the state's dependence on and involvement in society's generation of knowledge. ${ }^{71}$

Is this story of the state's exhaustion? A story about the end of the state? For better, or for worse? Are we asking the right questions? Selden, the Secretary of the Interior, knows these are the wrong questions. Or at maybe, they just have to be asked differently. If Selden's exhaustion is not different from the state's exhaustion, which is only a representation of society's exhaustion, we keep going in circles. At the same time, this is the only way, it seems, to ask a question. By paralleling Selden's exhaustion and questions with those of state and society, the author Kumpfmüller deprives everyone of a position of primacy or of occupying a privileged vantage point 'with a view'. Selden's exhaustion is the exhaustion of utopian Energies some thirty years ago when privatization came to substitute juridification, and contractualization began to sit side by side with administrative acts. Full employment then, September $11^{\text {th }}$ today. Exhausted institutions, exhausted utopias.

\footnotetext{
${ }^{71}$ Karl-Heinz Ladeur, Postmoderne Rechtstheorie (1992); Karl-Heinz Ladeur, Der "Eigenwert" des Rechts Die Selbstorganisationsfähigkeit der Gesellschaft und die relationale Rationalität des Rechts, in: DIE ZUKUNFT DES RECHTS 31 (Meier-Schatz Ed. 1998).
} 


\section{E. ACKERMANN's MARKET}

Let us move away from the books and turn our attention to codes of conduct, best practices, recommendations and corporate governance codes. These are the law's new text. We can study their emergence through the protagonists Josef Ackermann and Theodor Baums. The latter chaired the German federal government's corporate governance commission between 2000 and 2001 and prepared a comprehensive 300 pages report focusing on the needed repairs to the body of German stock corporation law with view to making it 'globally competitive'. The central recommendation of his report to the Ministry of Justice was to convene a follow-up commission with the mandate of drafting a Corporate Governance Code. This code would have to connect tradition and revolution: on the one hand, the code, which was issued a mere year later $^{72}$, in 2002, would have to present the central features of the existing law to the foreign reader (and prospective investor) in a concentrated and accessible manner. In this respect, the Code contains a largely descriptive portion related to the existing law governing stock corporations. On the other hand, the Code includes a long list of recommendations and suggestions that tell a tale of the slowly but surely evolving transformation of the German 'variety of capitalism' ${ }^{73}$ On the small space of fourteen pages, the Code thus brings together hard and soft law, the law of today and, perhaps, of tomorrow. ${ }^{74}$

The governing idea behind the Code is, admittedly, the creation of more transparency as well as the 'soft' governance of the market through a distinct form of inducing a publicly accountable self-regulation of German corporations adhering to the Code. If a corporation decides not to observe the recommendations of a Code, it must issue a statement to that effect in its annual report. The corporation is, however, not obliged to offer justifications. This is of great interest in the context of our inquiry into the 'how' of law's effectiveness. The brief, largely academic debate regarding the legal nature of the Code, including the question whether or not already the Commission itself had lacked a constitutional mandate to engage in law-making, ${ }^{75}$ eventually

\footnotetext{
${ }^{72} \mathrm{http} / / /$ www.corporate-governance-code.de/

${ }^{73}$ Sigurt Vitols, Varieties of Corporate Governance: Comparing Germany and the UK, in: VARIETIES OF Capitalism. The Institutional Foundations of Comparative Advantage 337 (Hall/Soskice Ed. 2001); John W. Cioffi, Restructuring "Germany Inc.": The Politics of Corporate Governance Reform in Germany and the European Union, 24 LAW \& POLICY 355 (2002); Peer Zumbansen, Germany Inc. Eroding? - Board Structure, CEO and Rhenish Capitalism, 3 GERMAN L. J. No. 6 (2002), available at: http://www.germanlawjournal.com/past_issues.php?id=156; Peer Zumbansen, The Privatization of Corporate Law? Corporate Governance Codes and Commercial Self-Regulation, JURIDIKUM 136 (2002b).

${ }^{74}$ Patrick C. Leyens, German Company Law: Recent Developments and Future Challenges, 6 German L. J. 1407 (2005), available at: http://www.germanlawjournal.com/article.php?id=645

${ }^{75}$ Peter Ulmer, Der deutsche Corporate Governance Kodex - ein neues Regulierungsinstrument für börsennotierte Aktiengesellschaften, 166 ZHR 150 (2002); Martin Wolf, Corporate Governance. Der Import angelsächsicher "SelfRegulation" im Widerstreit zum deutschen Parlamentsvorbehalt, ZRP 35 (2002), 59-60; Wolfgang Seidel, Kodex ohne Rechtsgrundlage, NeUE ZeITSCHRIFT FÜr GESELlsChAFTSRECHT [NZG] 1095 (2004); Markus Heintzen, Der Deutsche Corporate Governance Kodex aus der Sicht des deutschen Verfassungsrechts, 25 ZEITSCHRIFT FÜR WIRTSCHAFTSRECHT [ZIP] 1933 (2004).
} 
subsided as the Legislator avoided any reference to this issue when it codified the corporations' obligation to issue the annual statement regarding its compliance. ${ }^{76}$

Under the watch of a standing commission and in the face of a relatively dynamic academic debate regarding the Code's 'success', the Code has undergone a number of amendments over the years since its initial drafting. There is, to be sure, a continued lack of consensus with regard to the effectiveness of the Code as a means of (legal) regulation. Even with a growing number of adhering corporations, it is anything but clear whether there has been any 'impact', whether the Code has led to an improved standing of German corporations on global financial markets - a concern, certainly, that has been attaining yet an entirely more accentuated meaning in a context of dramatically scarce funds going around. This is aggravated by an underlying fundamental uncertainty about how to adequately measure the connection between a corporation's observance of the Code's soft law segments and its improved economic performance.

Mr Baums himself has been playing a particularly interesting role in the afterlife of the Code. He found himself, having stepped down from chairing a highly renowned commission in neverending media and academic attention, increasingly entangled in a complex web of official and unofficial, hard and soft laws. When faced with the resistance of German leading managers against the Code's plea to individually list the elements of executive compensation, Baums announced he would take this issue to Berlin, i.e. to lobby for the codification of this previously soft obligation. The train of the German economy's self-regulation was thus rerouted, with the result of an admittedly altogether not convincing law ordaining the individual listing of board members' compensation except where a qualified majority of shareholders chose to vote against this disclosure. ${ }^{77}$ What is the lesson learned? What does this tell us about law's effectiveness? This question gains particular relevance where we remember that the original question always carried a critical component with it: the inquiry into law's effectiveness is one that goes both ways. Inquiring into law's effectiveness implies a critique of the means and the end. This story speaks of the ambiguities that surround the emergence of new, alternative forms of regulation and it is an account of the challenges and intricacies of institutionalizing alternative modes of legal governance in a highly codified and formalized civil law system.

Arguably, then, the real hero of the transformation of German capitalism is Josef Ackermann. Assuming, in 2002, the role of Speaker and CEO of the Deutsche Bank, he left little doubt from the beginning as to his ambition to restructure the Board towards a the crucial role now occupied by himself. The French Le Monde promptly speculated about an eventual cultural revolution while German newspapers were no less imaginiative in their colourful picturing of the changes that would come of Ackermann's tenure. While many expected that Josef Ackermann, an ambitous manager of decidedly global orientation, would take the lead in order to fill the role of

\footnotetext{
${ }^{76}$ Henrik-Michael Ringleb, Vorbemerkung, in: KOMmENTAR zUm DEUTSCHEN CORPORATE GOVERNANCE KodeX (3. Aufl.) 16 (Ringleb/Kremer/Lutter/v. Werder Ed. 2008), annoation numbers 53-59.

77 Theodor Baums, Vorschlag eines Gesetzes zur Verbesserung der Transparenz von Vorstandsvergütungen, 25 ZEITSCHRIFT FÜR WIRTSCHAFTSRECHT [ZIP] 1877 (2004); Theodor Baums, Zur Offenlegung von Vorstandsvergütungen, 169 ZHR 299 (2005); Gerald Spindler, Das Gesetz über die Offenlegung von Vorstandsvergütungen - VorstOG, NEUE ZEITSCHRIFT FÜR GESELLSCHAFTSRECHT [NZG] 689 (2005).
} 
an authoritative CEO more than adhering to the existing collegial and consensual form of government prescribed by German stock corporation law, these concerns turned out to be somewhat unnecessary. Ackermann convened an executive committee, closely positioned around the Speaker, and this eventually resulted in a Group Executive Committee, consisting of members of the board but also of managers of other important business partners of the Bank. All's well that ends well? What about the relationship between the board of managers and the supervisory board, especially in light of the important legislative changes brought about in the past in order to improve the level of control of the latter over the former? ${ }^{78}$ The Deutsche Bank appears to be in loyal observance of the Code and itself propagates an effective communication with the supervisory board.

On its website, the Bank publishes a comprehensive report regarding its compliance with the Code and with other corporate governance principles it pursues. The level of (self)regulation is amplified to a degree that render the formal, official regulatory framework almost invisible. The Bank observes the Code, which itself is not law - as we are told by the drafting body - and it adheres to such corporate governance principles that have gained wide market accceptance.

And, in July 2008, Josef Ackermann was appointed honorary professor at the University of Frankfurt. Moreover, three years before, his nomination was successfully resisted by a number of University members including the student council (ASTA). Now, at the time of his final appointment, several University officials lauded this event as a 'successful integration of market and science'. Others commented on the appointment as a quid-pro-quo and as returned favors in light of the substantial financial gifts from the Bank to the University, in particular the banking and corporate law-focused Institute for Law and Finance. ${ }^{79}$ The German weekly, DER SPIEGEL, reported the University's Economics Department's Dean, Wolfgang König, to have observed that 'Ackermann was an expert, and his moral qualities were not at issue'. The Dean reportedly went on to say that Ackermann with his particular corporate policy had the interests of shareholders in mind, which itself was important teaching substance for students: 'He does banking strategy, he does banking structure, and these fields cannot be debated without touching on shareholder value, which formed a part of the curriculum. The Director of the Institute of Social Institute [and successor of Jürgen Habermas at the Department of Philosophy - PZ], originally founded by Adorno and Horkheimer, Professor Axel Honneth, has no quarrel with this assessment. Yet the many connections and ties between the University and Deutsche Bank, including the newly built 'House of Finance' on the University's new campus in the Westend of Frankfurt, co-financed by the Deutsche Bank, gave a somewhat stale taste to the fact that top managers of such important a sponsor received academic honorary titles. ${ }^{80}$ Students that were

\footnotetext{
${ }^{78}$ Klaus J. Hopt, The German Two-Tier Board: Experience, Theory, Reforms, in: COMPARATIVE CORPORATE Governance - The StAte of the ART AND EMERging ReSEARCH 227 (Hopt/Kanda/Roe/Wymeersch/Prigge Ed. 1998).

${ }^{79} \mathrm{http}: / / \mathrm{www}$. ilf-frankfurt.de/

${ }^{80}$ Ludger Fittkau, Streit über Honorarprofessur für Josef Ackermann, DER SPIEGEL online, 22.2.2008, http://www.spiegel.de/unispiegel/studium/0,1518,342537,00.html: „“Ackermann sei ein Fachmann, und es gehe
} 
interviewed back in February 2008, the year of Ackermann's appointment regretted the reduction in course offerings in the area of social care, welfare and pensions insurance in contrast to the increased offers of finance oriented courses.

This local example is hardly comprehensible without casting an eye to its transnational dimensions. The justifications offered by the Economics Dean can well be read as a reflection of a long-standing shifting of governance and subsistence balances between state and market. In contrast, the remarks of the Professor of Philosophy rings strangely helpless. In the face of such fast-changing relations between public and private and the pressure on actors on both sides, we are well advised to cast our view beyond the local context, into a world in which Niklas Luhmann raised the question whether it would still have any place (or role) of the law of the embedded national rule of law and welfare state. ${ }^{81}$

\section{F. Transnational LaW aS THE DEMiSe OF 'Legal GeOMETRY'? ${ }^{82}$}

We shall once more return to Habermas' $\operatorname{article}^{83}$ on the crisis of the Welfare State and the exhaustion of utopian energies. Habbermas refers to the historian Reinhart Koselleck and his work on the new time consciousness that emerges in the $18^{\text {th }}$ century:

A consciousness of time and the future begins to develop in the shadows of absolutist politics, first in secret, later openly, sustained by an audacious combination of politics and prophecy. There enters into the philosophy of progress a typical eighteenth-century mixture of rational prediction and salvational expectation. Progress occurred to the extent that the state and its

nicht darum, seine moralischen Qualitäten zu bewerten, argumentiert Wolfgang König, Dekan des Fachbereichs Wirtschaftswissenschaften. Dass Ackermann mit seiner Unternehmenspolitik besonders die Interessen der Aktionäre im Blick habe, sei sogar wichtiger Lernstoff für die Studenten: 'Er macht Bankenstrategie, er macht Bankenstruktur, er macht Kapitalmarktüberlegungen, und da spielen natürlich Fragen wie Shareholder value eine Rolle', sagt König, "insofern ist das schon ein Teil des Ausbildungsprogramms. Das sei in Ordnung so, glaubt auch der Philosophieprofessor Axel Honneth, Leiter des von Adorno und Horkheimer gegründeten Instituts für Sozialforschung an der Goethe-Universität. Allerdings gebe es inzwischen vielfältige Verflechtungen zwischen der Uni und der Deutschen Bank, die zum Beispiel das neue "House of Finance" auf dem Campus Westend mitfinanziere. Wenn dann Spitzenmanager dieses wichtigen Sponsors akademische Ehren-Titel bekämen, hätte das einen schalen Beigeschmack." [Engl. transl. PZ]

${ }^{81}$ Niklas Luhmann, DAs Recht Der Gesellschaft (1993), at 585 [Engl: The LAW Of Society, 2004].

${ }^{82}$ Marc Amstutz/Vagias Karavas, Rechtsmutation: Zu Genese und Evolution des Rechts im transnationalen Raum, RECHTSHISTORISCHES JOURNAL 14 (2006), at 15.

83 Jürgen Habermas, The New Obscurity: The Crisis of the Welfare State and the Exhaustion of Utopian Energies [1985], in: The New Conservatism. Cultural Criticism And the Historians' Debate [ed. and transl. by Shierry Weber Nicholsen] 48 (Habermas Ed. 1989), at 9. 
prognostication was never able to satisfy soteriological demands which persisted when a state whose own existence depended upon the elimination of millenarian expectations. ${ }^{84}$

It is the dramatic realization of the unavaibility of the future and the doubtfulness of the nationstate's past in face of emerging transnational regulatory regimes that might explain the urgency with which scholars today are engaged in the design of legal architectures for world society. Such exercises have long been forced to shed their optimism and innocence: too overwhelming proves the realization of (the recurrence, continuation of) exclusion, violence and stratification. ${ }^{85}$

And yet, the shadow of the state continues to loom large: the challenge amidst a dynamic debate over the future of international relations and international law $^{86}$ continues to be the translation between the semantics of 'law and politics' developed within the nation-state onto the transnational arena. For the time being, the distinct quality of the 'post-national constellation' ${ }^{87}$ seems to block our view back to the learning experiences within the nation-state. In this constellation it might be of some merit to focus on the relations between the parallels amongst the legal theoretical and legal sociological methodological instruments that have been evolving inside and outside of the nation state, if only to realize that at the core lies a new understanding of society and of its law. This understanding would be grounded in the realization that society is a world society and that our learned ways in tracing the evolution of law, economics, the state and 'society' reflect the particular historical and cultural contexts and experiences out of which such accounts of society have been arising. ${ }^{88}$ Such an approach would not be justifiable on the basis alone of wanting to avoid a crude transfer of nation-state originating legal methodologies into the discourses around transnational regulatory regimes; rather, the realization of the importance of the local would not have to lead us to the preaching of a possibly desired return to a world before globalization, but instead the emerging project would be about a reconnection between the evolution of legal semantics in different places, times and spaces. In other words, it would be about the connection between critical investigations into the tension between the legal and non-legal space within a highly regulated, adjudicated and administered space ${ }^{89}$ on the one

\footnotetext{
${ }^{84}$ Reinhart Koselleck, Modernity and the Planes of Historicity, 10 ECONOMY AND SOCIETY 166 (1981), reprinted in Reinhart Koselleck, Futures Past. On the Semantics Of Historical Time [Transl. and with an introduction by Keith Tribe, 2004], 9-25, at 21.

${ }^{85}$ See, e.g., Antony Anghie, Imperialism, Sovereignty and the Making of International LaW (2005); NikLas Luhmann, LAW as a Social System (K.Ziegert transl., F.Kastner, D.Schiff, R.Nobles, R.Ziegert eds.) (2004), ch. 12; Nancy Fraser, Scales of Justice. Reimagining Political Space in a Globalizing World (2009).

${ }^{86}$ See, e.g., Oona A. Hathaway/Ariel N. Lavinbuk, Rationalism and Revisionism in International Law, 119 HARV. L. ReV. 1404 (2006); Paul Schiff Berman, Seeing Beyond the Limits of International Law: Jack L. Goldsmith/Eric A. Posner, The Limits of International Law, 84 TEXAS LAw REVIEw 1265 (2006); JÜRGEN HABERMAS, THE Divided WEST (2006).

87 JÜrgen Habermas, The Postnational Constellation (2001).

${ }^{88}$ For a discussion see John Meyer et al., World Society and the Nation-State, 103 AMERICAN SociologiCAL REVIEW 144-181 (1997).

${ }^{89}$ Robert M. Cover, Nomos and Narrative, 97 HARV. L. REV. 4 (1983)
} 
hand and a seeminmgly more amorphous space on the other. ${ }^{90}$ From that perspective, we are likely to gain a better view on such fields that so far might have been the terrain of specialized discourses, including the transnationalization of labour movements and employment and workplace regulations ${ }^{91}$, migration and citizenship ${ }^{92}$, the transformation of actual and theoretical access and user conditionalities of educational facilities ${ }^{93}$ as well as questions arising from the administration of cities with regard to exclusion and inclusion of urban populations. Further fields that demand a more concentrated investigation into their transnational dimension between the local and the global are employment and corporate law as well as the connection between these mostly isolated discourses. ${ }^{94}$ With regard to "practical legal questions ${ }^{95}$ or to the neverending need to justify interdisciplinary ${ }^{96}$ and methodological inquiry into legal doctrine ${ }^{97}$, it is obvious that there is much that legal sociology and theory have to offer. That legal sociology is 'in a crisis ${ }^{98}$ might thus be somewhat exaggerated. But, at the same time, there is no compelling reason to assume that current reform processes in legal education were in fact whole- or even halfheartedly taking the hands that legal sociology and theory are extending into their direction. How come?

\footnotetext{
${ }^{90}$ SASkia SASSEn, Territory - Authority - Rights. From MedieVal to Global AsSEmblages (2006); Saskia Sassen, The Places and Spaces of the Global: An Expanded Analytic Terrain, in: Globalization TheORY. APPROACHES AND CONTROVERSIES 79 (Held/McGrew Ed. 2007)

${ }^{91}$ SASKia SASSEn, THE Mobility of LABOR AND CAPITAL. A STUDY IN INTERNATIONAL INVESTMENT AND LABOR FLOW (1988); Harry W. Arthurs, Labor Law Without the State, 46 UnIVERSITY OF TORONTO LAW JOURNAL 1 (1996); Jennifer Gordon, Towards Transnational Labor Citizenship: Restructuring Labor Migration to Reinforce Workers Rights, Working Paper, Fordham Law School, January 2009, available at: http://ssrn.com/abstract=1348064

${ }^{92}$ Catherine Dauvergne, Making People Illegal: What Globalization Means for Migration and LaW (2008)

${ }^{93}$ KARL-Heinz Ladeur, Der StaAt Gegen die GeSellschaft (2006), chap. IV B

${ }^{94}$ Harry W. Arthurs, Private Ordering and Workers' Rights in the Global Economy: Corporate Codes of Conduct as a Regime of Labour Market Regulation, in: LABOUR LAW IN AN ERA OF GlobalizATION. TRANSFORMATIVE PRACTICES AND POSSIBILITIES 471 (Conaghan/Fischl/Klare Ed. 2002); Peer Zumbansen, The Parallel Worlds of Corporate Governance and Labor Law, 13 INDIANA JOURNAL OF GLOBAL STUDIES 261 (2006)

${ }^{95}$ MANFRED ReHBinder, Rechtssoziologie, 5. Aufl. (2003), S. 8

${ }^{96}$ ERHard Blankenburg, Mobilisierung Des Rechts. Eine EINFÜHRUNG IN DIE RECHTSSOZIOLOGIE (1995)

${ }^{97}$ Thomas Raiser, Grundlagen Der Rechtssoziologie, 4. Aufl. (2007); Karl-Ludwig KunZ/Martino Mona, RECHTSPHILOSOPHIE. RECHTSTHEORIE. RECHTSSOZIOLOGIE (2006), 109, 221

${ }^{98}$ Michael Wrase, Rechtssoziologie und Law and Society : Die deutsche Rechtssoziologie zwischen Krise und Neuaufbruch, 27 ZEITSCHRIFT FÜR RECHTSSOZIOLOGIE 289 (2006)
} 